Jan Paweł II. Posługa myślenia, t. 2, red. ks. B. Kastelik, A. Krupka, ks. R. Woźniak, Kraków 2015, s. 119-140

(Studia nad Myślą Jana Pawła II, 17).

DOI: http://dx.doi.org/10.15633/9788374384933.08

Rafał Kazimierz Wilk OSPPE

\title{
CZŁOWIEK - OSOBA - ISTOTA WOLNA. UJĘCIE KAROLA WOJTYŁY
}

Kim jest człowiek? Kim jestem „ja”? Nie ma chyba wątpliwości, że pytania te należą do najważniejszych i najciekawszych pośród tych, które nieusuwalnie stają przed człowiekiem i na które każdy musi dać jakąś odpowiedź. Nic przeto dziwnego, że stały się one szczególne ważne dla Karola Wojtyły: filozofa, kapłana, biskupa, kardynała, wreszcie papieża - człowieka, na którym spoczęła odpowiedzialność nie tylko za jego własne życie, ale jako namiestnika Chrystusowego, za życie wszystkich ludzi. Ich doniosłość odzwierciedla się w jego publikacjach, poczynając od artykułów, poprzez książki Miłość i odpowiedzialność, Osoba i czyn, aż do nauczania papieskiego, ujętego w całym bogactwie wypowiedzi, zwłaszcza poprzez encykliki.

$\mathrm{W}$ przedkładanym tu, z konieczności krótkim opracowaniu, będziemy starali się zaledwie wskazać, i to jedynie najważniejsze, wątki personalistyczne obecne w myśli Karola Wojtyły, czyniąc głównym przedmiotem naszych analiz jego zasadnicze filozoficzne dzieło Osoba i czyn.

Już na wstępie podkreślmy dwie ważne sprawy natury metodologicznej. Po pierwsze, trzeba zaznaczyć, że chociaż Karol Wojtyła w swoich badaniach antropologicznych pozostawał wierny dorobkowi filozoficznemu szkoły perypatetycznej, to jednak nie zamknął się w niej, ale równocześnie korzystał z owoców metody fenomenologicznej wypracowanej przez Edmunda Husserla na tzw. realistycznym poziomie. Filozofia arystotelesowsko-tomistyczna, twierdził Wojtyła, trafnie ujmuje człowieka w wymiarze kosmologicznym, czyli jako byt pośród bytów. Natomiast nie jest sposobna do odkrycia tego, co w człowieku jest „nieredukowalne”, a temu ostatniemu właśnie omawiany Autor w swoim wysiłku poznawczym skierowanym na osobę ludzką dawał 
pewne pierwszeństwo, swoistą przewagę. Można powiedzieć, że Karolowi Wojtyle chodziło o to, ażeby w prowadzonych filozoficznych eksploracjach nie zaniedbać niczego, co jest istotne dla zrozumienia bytu „człowiek”; chciał badać człowieka jako byt obiektywny, ale taki, który jest ukonstytuowany również przez swoją subiektywność, (czego w żadnym przypadku nie można mylić ze subiektywizmem).

W jednej ze swoich rozpraw pisał: „Nie sposób zakwestionować przydatności definicji Arystotelesowskiej, która utrwaliła swoje panowanie na gruncie metafizycznej antropologii i patronowała powstaniu wielu nauk szczegółowych o człowieku rozumianym właśnie jako animal, z wyróżniającą go cechą rozumności. Cała tradycja nauki o złożoności natury ludzkiej, o duchowo-cielesnym compositum humanum [...] porusza się [...] na gruncie przeświadczenia o zasadniczej redukowalności (= sprowadzalności) tego, co istotowo ludzkie, do «świata» [...]. Z drugiej strony wydaje się jednak, że przeświadczenie o pierwotnej oryginalności istoty ludzkiej, o jej - wobec tego - zasadniczej niesprowadzalności do «świata», do przyrody, jest równie dawne, jak potrzeba redukcji wyrażona definicją Arystotelesa"'. Doświadczalne dotarcie do tego, co jest „niesprowadzalne do świata”, co „nieredukowalne” w człowieku, jest możliwe po odwołaniu się do tego specjalnego doświadczenia, jakim jest przeżycie, a tę możliwość wnosi właśnie metoda fenomenologiczna. A zatem, o ile nie można zaniedbać, bez szkody dla zrozumienia człowieka, owoców badań filozofii arystotelesowsko-tomistycznej, filozofii typu metafizycznego czy kosmologicznego, o tyle nie można powiedzieć, że wyczerpuje się w niej filozoficzna eksploracja bytu ludzkiego. Jest on bowiem ontycznie ukonstytuowany przez coś, co nie daje się zredukować, „co domaga się wprowadzenia do analizy bytu ludzkiego aspektu świadomości”. I ten typ zrozumienia Wojtyła określa jako „personalistyczny”; jemu też przyznaje swoiste pierwszeństwo wobec ujęcia typu kosmologicznego. W badaniach antropologicznych - podkreśla krakowski filozof - właśnie wymiarowi personalistycznemu „trzeba pozostawiać [...] więcej miejsca”"2.

Wielu krytyków postawę przezeń przyjętą uważało za niewłaściwą, a nawet dopatrywali się w niej odejścia od filozofii ${ }^{3}$. Chyba najbardziej skrajne

$1 \quad$ K. Wojtyła, Podmiotowość i „to, co nieredukowalne” w człowieku, [w:] tegoż, „Osoba i czyn" oraz inne studia antropologiczne, Lublin 1994, s. 437.

Tamże, s. 440.

Zobacz na ten temat materiał z dyskusji, która odbyła się na Katolickim Uniwersytecie Lubelskim, wydany drukiem w: „Analecta Cracoviensia” 5-6 (1973-1974). 
stanowisko w tym względzie zostało wyrażone przez Jerzego Kalinowskiego, według którego „metafizyka osoby leży poza książką ks. Kardynała, że ledwie na jej horyzoncie majaczy, będąc założoną i jedynie krótko, bez uzasadnienia, to tu, to tam wzmiankowaną, że Osobę $i$ czyn wypełnia analiza fenomenologiczna rzekomo danych oglądowych - a moim zdaniem założeń metafizycznych skonfrontowanych $\mathrm{z}$ doświadczeniem - studium omawiane nie posiada charakteru filozoficznego we właściwym słowa znaczeniu" - konkluduje ${ }^{4}$. Wydaje się jednak, że niejako uprzedzająco, po stronie Wojtyły stanął inny wybitny polski filozof, ks. Konstanty Michalski. Ów były rektor Uniwersytetu Jagiellońskiego tak niegdyś wyraził swoje stanowisko w tym względzie. Pisał: „Tomistyczna filozofia uważa się za filozofię nie zamkniętą, lecz otwartą tak, iż wszelkie wyniki myślenia nawet gdzie indziej zdobyte z natury rzeczy do niej należą"

Po drugie, Wojtyła dokonuje wglądu w człowieka poprzez analizę właściwych bytowi ludzkiemu dynamizmów. Wykazuje on przeto, iż w człowieku są trzy dynamizmy, za którymi, jako ich źródło, stoją trzy struktury bytowe. Są to: a) cielesność $z$ dynamizmem reaktywnym; b) psychika $z$ dynamizmem emotywnym; oraz c) osoba $z$ dynamizmem osobowym.

\section{Ciało człowieka}

Badając i wyjaśniając problematykę ludzkiej cielesności, Wojtyła odwołuje się do filozofii klasycznej, do przemyśleń Arystotelesa i św. Tomasza z Akwinu, a więc tego systemu, który głosi teorię hylemorfizmu, wyraźnie wskazuje na materialny czynnik konstytuujący człowieka. Ukazuje on bowiem byt ludzki jako ciało (materia - hyle), zaktualizowane przez formę (morfe $)^{6}$. Aby uwyraźnić wagę fizycznego aspektu bytu ludzkiego, jak mocno jest on podkreślany przez filozofów, przywołuje Wojtyła klasyczną definicję. W Osobie i czynie czytamy: „Przynależność ciała do osoby ludzkiej jest tak ściśle konieczna, że wchodzi do definicji człowieka - przynajmniej w sposób pośredni, tak jak do najczęściej używanej «homo est animal rationale»: w pojęciu animal zawiera

$4 \quad$ J. Kalinowski, Metafizyka i fenomenologia osoby ludzkiej. Pytania wywołane przez „Osobę i czyn”, „Analecta Cracoviensia” 5-6 (1973-1974), s. 69.

$5 \quad$ K. Michalski, Nieznanemu Bogu, [w:] tegoż, Nova et Vetera, Kraków 1998, s. 486.

6 K. Wojtyła, Osoba i czyn, [w:] tegoż, „Osoba i czyn” oraz inne studia antropologiczne, Lublin 1994, s. 243. 
się ciało i cielesność. Ciało stanowi o konkretności człowieka, czemu poniekąd dała wyraz metafizyczna teza o ujednostkowieniu człowieka przez materię"7.

Ciało człowieka posiada swój dynamizm, który przejawia się w „ruchliwości” ${ }^{8}$. Dynamizm ten można określić jako „reaktywny”, a jego potencjalność - potencjalnością reaktywną. A zatem potencjalność ciała ludzkiego, na podobieństwo innych ciał w przyrodzie, posiada zdolność do reakcji, która charakteryzuje człowieka w zakresie cielesnej żywotności. Żywotność ta ma charakter wegetatywny, stąd też życie własne ludzkiego ciała jest wegetacją, której początek stanowi poczęcie, a kres - śmierć. Dynamiczną osnowę tej żywotności stanowi ciąg reakcji czysto instynktownych, a więc takich, które dokonują się na sposób samej natury (rozumianej na sposób fenomenologii bądź nauk szczegółowych). Dokonują się, czyli „dzieją się” w człowieku, ale bez wpływu woli, bez właściwego osobie udziału samostanowienia. $Z$ tej racji mówimy o nich, że chociaż dzieją się one w człowieku-osobie, to jednak nie stanowią działania osoby. Ciało „uczynnia” się samo zgodnie z wewnętrzną celowością wegetacji czy reprodukcji. Reaktywność ciała człowieka oznacza przeto instynktowny oraz dynamiczny związek z przyrodą, jako z zespołem uwarunkowań zewnętrznych wegetacji i reprodukcji. Specyfiką somatycznej potencjalności człowieka jest zdolność reagowania na bodźce. Jest ona związana z systemem nerwowym, który to wyznacza poszczególne kierunki reaktywnego dynamizmu oraz potencjalności somatycznej. Jest to dynamizm samorzutny, instynktowny, a ciało stanowi nie tylko jego podłoże, ale również jego źródło, a więc i jego przyczynę sprawczą. Tak więc w przypadku dynamizmu cielesnego jego przyczyną nie jest wola i nie zawiera w sobie momentu samostanowienia ${ }^{9}$. „Dlatego też - pisze Wojtyła - nie odnajdujemy go (dynamizmu somatycznego - przyp. R. K. W.) wprost i bezpośrednio w doświadczeniu «człowiek działa», które ujawnia sprawczość osoby, ale tylko w doświadczeniu «coś dzieje się w człowieku», gdzie sprawczość osoby jest nieobecna. Reakcja i reaktywność sama z siebie nie zawiera sprawczości osoby. Można mówić wówczas o jakiejś własnej sprawczości ciała, która tkwi w osobie na zasadzie ontycznej jedności człowieka"10. Owo wyróżnienie dynamizmu osobowego i dynamizmu cielesnego sprawia, iż ciało jawi się nam w całokształcie osobowej struktury człowieka jako „podbudowa” czy

Tamże, s. 243-244.

Tamże, s. 144, 248.

Tamże, s. 249-251.

Tamże, s. 251. 
„pod-struktura” w relacji do podmiotowości osobowej. Jednakże złożoność ta nie przeczy jedności bytu człowieka ${ }^{11}$. „Jest rzeczą jasną - czytamy - iż podbudowa ta należy do jedności bytu ludzkiego, a więc do jedności osoby. Co więcej, na zasadzie wewnętrznych więzi i uwarunkowań stanowi ona o integralności tego bytu. Fakt, że właściwy ciału ludzkiemu dynamizm reaktywny oraz właściwa mu żywotność wegetatywna «dzieje się» w osobie niezależnie od jej samostanowienia, bez czynnego wdawania się woli, nie przekreśla w niczym tej jedności. Podobnie jak nie przekreśla jej fakt, iż cała żywotność wegetatywna i reaktywność ciała ludzkiego prawidłowo przebiega w człowieku poza zasięgiem świadomości. Fakt ten [...] nie przekreśla bynajmniej osobowej jedności człowieka, chociaż na swój sposób ją charakteryzuje"12. A zatem ciało - struktura bytująca i dynamizująca się na sposób natury - jest „wbudowane”, w jedność struktury osobowego bytu „człowiek” i nie stanowi jakiegoś odrębnego $\mathrm{w}$ stosunku doń podmiotu. Jedność ta, tj. ciała $\mathrm{z}$ jego suppositum osobowym, nie ulega zakwestionowaniu. I choć w przeżyciu siebie jako podmiotowego ,ja” ciało objęte jest przeważnie tylko od zewnątrz, to przecież wystarcza to człowiekowi do przeżycia jego własnej podmiotowej całości i jedności, wszak nie musi on w tym celu uświadamiać sobie wszystkich reakcji zachodzących wewnątrz jego organizmu.

Niemniej możemy też powiedzieć, że ciało jest czymś, co jakoby posiadało swoistą, „podmiotowość” w obrębie podmiotowości człowieka. Mówimy ,jakoby posiadało", wszak jest to podmiotowość odrębna, jednakże nienaruszająca całościowej podmiotowości ontycznej człowieka. Byłaby to podmiotowość w takim znaczeniu, że ciało, stanowiąc właściwy podmiot reakcji, tworzyłoby podmiotowość reaktywną, wegetatywną i zasadniczo pozaświadomościową. Ale podmiotowość ta jest ostatecznie zintegrowana w człowieku-osobie i z podmiotowością osoby i razem tworzą byt ludzki ${ }^{13}$. „Integralność człowieka-osoby polega na normalnym - i owszem, o ile możności - doskonałym zestrojeniu tej somatycznej "podmiotowości» ze sprawczą i transcendentną podmiotowością osoby" ${ }^{\prime 4}$.

Dynamizm osobowy, choć jest różny od sfery cielesnej człowieka, to jednak uzewnętrznia się on również w ciele i poprzez ciało, a dokonuje się to

\footnotetext{
11 Tamże.

12 Tamże, s. 251-252.

13 Tamże, s. 252.

14 Tamże.
} 
w czynie ${ }^{15}$, „Ciało ludzkie - pisze Wojtyła - [...] w swej widzialnej dynamice jest terenem, jest poniekąd nawet środkiem ekspresji dla osoby. Ściśle osobowa struktura [...] przebiega niejako poprzez ciało i w nim się wyraża. Struktura ta, jak wiadomo, wyraża się w czynie i poprzez czyn się urzeczywistnia"16.

\section{Psychika człowieka}

Czym jest psychika w ujęciu przedstawionym przez Wojtyłę? Nie utożsamia się tu ona z duszą człowieka, choć przecież słowo „psychika” etymologicznie pochodzi od greckiego słowa psyche, co właśnie znaczy „dusza”. Tutaj słowo „psychika” (czy psychiczne) wyraża te pierwiastki człowieczeństwa, które w doświadczeniu są zintegrowane z ciałem, a jednocześnie same w sobie nie są tym ciałem, te, które znajdują swój doświadczalny wyraz w dynamizmie psycho-emotywnym. A zatem, pomimo tego, że „psychika” jest czymś różnym od „somatyki”, to jednak w człowieku stanowią one wzajemnie warunkującą się jedność. Jest to jednakże jedność ukonstytuowana z różnorodności i obydwie te bytowe struktury nie dadzą się do siebie zredukować.

Psychika, jako odrębny element ontyczny, posiada sobie właściwy dynamizm - „dynamizm emotywny”. „Emotywność” w powszechnym ujęciu zwykle kojarzy się z rzeczownikiem "emocja”, a "przeżycie emocjonalne” bywa rozumiane jako „przeżycie uczuciowe”. Jednakże poprzestanie tylko na takim jego rozumieniu byłoby pewnym zubożeniem, uproszczeniem, nie prezentowałoby całego zakresu jego treści. Termin „emotywnośc” wskazuje bowiem nie tylko na uczucia, ale ma on o wiele szersze znaczenie, zawiera bowiem w sobie cały „świat” ludzkich „czuć”. O ich wielości niech świadczy kilka pojęć, które zawierają w sobie ten sam rdzeń. Mówimy np. o uczuciach, czuciach, odczuciach, poczuciach, wyczuciach, przeczuciach, ponadto z przydawkami jak np. o odczuciu artystycznym, poczuciu moralnym itp. To wielkie bogactwo określeń wskazuje na szeroki zakres ludzkich „czuć”, a przez to samo na szersze i właściwe znaczenie emotywności.

Etymologicznie słowo „emocja” wskazuje na „ruch”, na „poruszenie się" pochodzące $\mathrm{z}$ wewnątrz (movere - ruszać się). Niestety, w języku polskim nie ma odpowiedniego słowa, które dobrze oddawałoby zawartość treściową emocji i emotywności.

\footnotetext{
15 Tamże.

16 Tamże, s. 244-245.
} 
Emotywność (jak i reaktywność) związana jest z działaniem bodźców. Jednak w wypadku emotywności skutek, jaki ów bodziec wywołuje, nie jest somatyczny, nie polega bowiem na reakcji (ruchu) ciał; skutek ten jest psychiczny i wyraża się w czuciu. Mimo tej odmienności skutek psychiczny wyraża się również pewną reakcją $\mathrm{w}$ warstwie somatycznej, chociaż sam w sobie reakcje te przekracza ${ }^{17}$. Wyjaśniając to, Wojtyła pisze: „Reakcja uczuciowa różni się zasadniczo od reakcji ruchowej choć bardzo często idą ze sobą w parze (gdy np. ktoś przy dotknięciu gorącego pieca odruchowo cofa rękę). Czucie samo w sobie nie jest żadnym ruchem czy odruchem somatycznym. Wykazuje ono taki stosunek do ciała, jak podmiot do przedmiotu: chociaż stosunek ten nie jest $\mathrm{w}$ samym czuciu uświadomiony, to przecież ciało staje się w nim pewną treścią, która zarazem przenika w pole świadomości. Tak więc poprzez czucia wydobywamy się ponad to, co [...] zostało nazwane podmiotowością samego ciała" ${ }^{18}$. Różnica pomiędzy podmiotowością somatyczną a psychiczną polega ponadto na tym, że pierwsza $\mathrm{z}$ nich, $\mathrm{w}$ znacznej mierze, nie jest objęta świadomością, druga zaś jest nią objęta w pełni. Jeżeli bowiem chodzi o własne ciało (zwłaszcza o jego wewnętrzność), to zakres uchwycenia go przez świadomość bywa właśnie wyznaczany głównie poprzez „pole czuć”. Zasadniczo bowiem znajduje się ono jakby poza zasięgiem świadomości, o ile nic z niego nie przeniknie w pole czuć (np. bólu). Zagadnienie czucia własnego ciała jest ważnym punktem przy omawianiu integralnej całości podmiotowej człowieka. Wszak w przeżyciu pewnego „czucia” ciało i świadomość są ze sobą związane właśnie przez czucie. W nim bowiem ciało i świadomość wiążą się ze sobą w sposób doświadczalny. Tak więc w człowieku jego świadomość, psychika i somatyka tworzą zintegrowaną całość w osobowym bycie człowieka ${ }^{19}$.

Przeprowadzone przez Wojtyłę analizy dotyczące psychiki człowieka pozostawiają w czytelniku pewien niedosyt. Chociaż są one dokonane trafnie i poprawnie opisują miejsce psychiki w bycie „człowiek”, to jednak nie podejmują ważnych w tym względzie rozróżnień.

Wojtyła nie bada i nie przedstawia tych zróżnicowań, gdyż zdaje się przyjmować, przez założenie, pewną linię interpretującą myśl św. Tomasza. W odniesieniu do przemyśleń Doktora Anielskiego dotyczących psychizmu człowieka łatwo daje się zauważyć dwa podejścia. Pierwsza grupa tomistów wszystkie „czucia” zamyka w jednym zbiorze, druga natomiast wyróżnia

\footnotetext{
17 Tamże, s. 264-269.

18 Tamże, s. 269.

19 Tamże, s. 270-272.
} 
w nim dwa podzbiory. Wojtyła zdaje się należeć do tej pierwszej; reprezentuje ją także inny wybitny polski filozof Stefan Swieżawski. Ten ostatni na interesujący nas temat pisał: „Jeżeli się mówi, że św. Tomasz obniża wartość uczuć, to tylko w tym sensie jest to słuszne, że Tomasz nie mógłby uznać zakorzenionego w wiele wieków później, mniej więcej od Kanta, czyli od końca XVIII w., obyczaju, zgodnie z którym wymienia się jednym tchem trzy władze duchowe, czyli umysłowe człowieka: rozum, wolę i uczucia. Według św. Tomasza uczucia nie należą do sfery umysłowej i w tym sensie można by twierdzić, że Tomasz uczucia degraduje. Ta koncepcja jest dość rozpowszechniona, dość często szafuje się formułą: «rozum, wola, uczucie». Dla Tomasza są tylko dwie władze umysłowe, czyli duchowe w człowieku, a mianowicie intelekt (z tym, że są, jak wiemy dwa intelekty: możnościowy i czynny) i wola. Uczucia natomiast, przy całej swojej ważności, znajdują się w sferze zmysłowej. To jest ważne z punktu widzenia wychowawczego: mieć świadomość, gdzie uczucia się lęgną i jakie jest ich miejsce w całokształcie życia psychicznego człowieka. A więc całe kłębowisko pragnień, odczuć, doznań znajduje się pod wpływem tego, co nazywamy uczuciami; mieści się w sferze nierozumnej człowieka, w tej sferze, która jest jeszcze nieintelektualna, nieumysłowa, tylko wspólna nam i zwierzętom. Jest to zarazem sfera, nad którą powinna panować oświecona intelektem wola. Jeżeli nie ma tej władzy woli i intelektu nad uczuciami, wtedy one najczęściej przejmują rolę czynników kierujących w naszym życiu, postępowaniu i twórczości, a to jest moralnie szkodliwe i niewłaściwe"20.

Dla cytowanego autora wszystkie fakty psychiczne tworzą jeden zbiór. Podkreśla on przy tym, że takie właśnie rozumienie jest bardzo ważne dla procesów wychowawczych. Uwaga ta jest znamienna, gdyż poniżej przytoczymy wypowiedź Konstantego Michalskiego, który twierdzi, że „tomizm odróżnia uczucia zmysłowe i duchowe afekty" ${ }^{21}$, a dostrzeżenie tego zróżnicowania jest ważne i doniosłe właśnie ze względów wychowawczych. „Ze szczególnym naciskiem chciałbym tu podkreślić dwupoziomowość uczuć w nauce św. Tomasza - pisze Michalski. Najwyraźniej wyodrębnia on uczucia zmysłowe, związane ze wzruszeniami (passiones), i uczucia wyższe, związane z wolą (affectus). Nawet niektórzy tomiści nie mają zrozumienia dla tej dwupoziomowości. Zapomina się mianowicie o wyższych uczuciach i ogranicza się do rozważań w obrębie uczuć zmysłowych. Jest to niesłychanie doniosła

\footnotetext{
20 S. Swieżawski, Św. Tomasz na nowo odczytany, Kraków 1983, s. 181-182.

21 K. Michalski, Między heroizmem a bestialstwem, Kraków 2010, s. 291.
} 
sprawa dla wychowania. Trzeba bowiem pamiętać o tym, że u dzieci i wśród młodzieży powstają uczucia na niższym i wyższym poziomie. Czasem gromi się wszelkie uczucia jako wroga i intruza, gdy tymczasem uczucia niższe są żywiołem, który trzeba ukształtować, a wyższe, są wyrazem naszego ducha”22.

Jeszcze mocniej i wyraźniej rolę uczuć w bycie człowieka przedstawia fenomenolog Dietrich von Hildebrand. Uważa on, że filozofowie, zaniedbując badania dotyczące uczuć, wręcz dokonują swoistej manipulacji, gdyż zamiast badać i opisywać człowieka prawdziwego, oni „konstruują” człowieka, który nie istnieje. Pisze on: „Cały Psałterz mówi o sercu jako o centrum, toteż kto ma uszy do słyszenia, usłyszy jego wielki i wspaniały głos w słowach proroków i naszego Pana. $Z$ tekstów filozoficznych na temat serca i sfery uczuciowości wyłania się jednak zupełnie inny obraz. To, co stanowi centrum człowieka, traktowane jest w nich jako rzecz mniej poważna, głęboka i ważna niż rozum i wola. Jest to przypadek drastycznego abstrakcjonizmu niosącego w sobie niebezpieczeństwo konstruowania teorii o rzeczywistości bez odwoływania się do niej. Ta postawa filozoficzna nieuchronnie rozmija się z faktami. Poruszamy się w dwóch odrębnych światach; jeden to świat serca w życiu człowieka, w Piśmie Świętym i w liturgii, drugi to filozoficzna teoria «afektów».

Filozofia rzeczywiście aż do tej pory nie przyznała sercu należnej mu rangi. Podczas gdy rozum i wola stały się przedmiotem gruntownych badań, serce pozostało $\mathrm{w}$ cieniu. Jeśli nawet zajmowano się nim, to przyznawano mu pozycję nieporównywalną z rozumem czy wolą, która nie odpowiada rzeczywistemu znaczeniu i godności tego ośrodka duszy ludzkiej. Rozum i wola stawiane były zawsze wyżej od serca [...] A właśnie to serce Pana Jezusa, a nie rozum lub wola, stało się przedmiotem osobnego kultu. Fakt ten, w którym przejawia się działanie Opatrzności i Kościoła, powinien być dla nas wezwaniem do głębszego zrozumienia serca, a tym samym do zrewidowania naszego stosunku do sfery uczuć w ogóle"23.

Być może pewne obawy w odniesieniu do zajmowania się uczuciami spowodowały błędy Davida Hume’a, który zrujnował i zdegradował człowieka przez podporządkowanie uczuciom nawet rozumu ${ }^{24}$. Niemniej jednak

22 Tenże, Spotkanie z prawdą, Kraków 1982, s. 30-31. Zob. także A. Willwoll, Seele Und Geist, Freiburg im Br. 1938, s. 125-126.

23 D. von Hildebrand, Serce, przeł. J. Koźbiał, Poznań 1985, s. 27.

24 Szerzej na ten temat zob. np. K. Wojtyła, O kierowniczej i służebnej roli rozumu $w$ etyce na tle pogladów św. Tomasza z Akwinu, Hume’a i Kanta, [w:] tegoż, Zagadnienie podmiotu moralności, Lublin 1991, s. 213-229. 
niczyje błędy nie mogą prowadzić do zaniechania badań, badań niezwykle ważnych zarówno tak np. dla teoretycznej antropologii filozoficznej, jak i dla praktycznej teologii życia wewnętrznego. Trzeba bowiem zapytać, czy zaniedbanie rozwoju uczuć duchowych nie może stać się przyczyną pewnego niedorozwoju duchowego, powodem nieosiągnięcia stosownego, możliwego rozwoju duchowego człowieka?

\section{Podmiotowość osobowa}

Oprócz struktury cielesno-psychiczej byt „człowiek” jest ontycznie ukonstytuowany przez pierwiastek duchowy, czyli duchową duszę ludzką, która jest poznawczo uchwytywana w doświadczeniu transcendencji osoby w czynie. Wojtyła pisze, że „wszystko to, co składa się na transcendencję osoby w czynie, co o niej stanowi, jest duchowe. Ponieważ wszystko to [...] wchodzi w zasięg doświadczenia fenomenologicznego, zatem przekonanie o duchowości człowieka $\mathrm{w}$ jej autentycznych przejawach nie jest wynikiem tylko jakiejś abstrakcji, ale - jeżeli tak można się wyrazić - posiada swój kształt oglądowy. Duchowość jest otwarta dla oglądu, a także dla wglądu"25. Duchowość jest dostępna dla oglądu w jej skutkach. Skoro istnieją niematerialne skutki, to musi istnieć proporcjonalna, adekwatna ich przyczyna; człowiek musi posiadać jakiś pierwiastek duchowy. „Wszystkim przejawom duchowości człowieka - kontynuuje wyjaśnienia Wojtyła - [...] musi odpowiadać realna immanencja ducha, pierwiastka duchowego w człowieku. Człowiek nie może przejawiać duchowości, jeżeli w jakiś sposób nie jest duchem. Za takim postawieniem sprawy przemawiają podstawowe zasady rozumienia całej rzeczywistości: zasada niesprzeczności i racji wystarczającej" ${ }^{26}$. Zatem o istnieniu duszy i jej duchowej naturze wnioskujemy ze skutków; człowiek doświadcza tylko skutków - przyczyn zaś musi poszukiwać. Źródłowym doświadczeniem w tym względzie jest więc doświadczenie czynu. Człowiek spełnia czyny, ponieważ jest osobą, to znaczy, że ujawnia on w sobie struktury samoposiadania i samopanowania oraz zakorzenionego w nich samostanowienia.

Chociaż podstawowym członem struktury osoby ludzkiej jest samoposiadanie, to jednak w porządku doświadczenia pierwotnie jest nam dane samostanowienie. Samoposiadanie jest doświadczalnie dane w przeżyciu „ja-chcę”

\footnotetext{
25 K. Wojtyła, Osoba i czyn, dz. cyt., s. 223.

26 Tamże, s. 224.
} 
i każde takie przeżycie zawiera w sobie moment samostanowienia. Człowiek poprzez wybór ",ja-chcę”, doświadcza aktu swojej własnej woli, spełnia „czyn”, potwierdza samoposiadanie i stanowi siebie ${ }^{27}$.

Samostanowienie ujawnia zatem samoposiadanie. Jest to sprawa oczywista, przecież ażeby o czymś stanowić, trzeba to najpierw posiadać. „Proste przeżycie «ja-chcę» nie może być w dynamicznym, całokształcie człowieka odczytane poprawnie - pisze Wojtyła - jeśli nie uwzględnimy w nim owej specyficznej, osobie tylko właściwej złożoności, jaką wnosi samo-posiadanie. Tylko na jego gruncie możliwe jest samostanowienie, a każde «chcę» jest takim właśnie samostanowieniem. Jest nim nie jako wyrwana z dynamicznej całości treść przeżycia, ale jako treść w całości tej głęboko zakorzeniona. «Chcę» jako aktualne samo-stanowienie zakłada strukturalnie samo-posiadanie. Stanowić bowiem można tylko o tym, co się realnie posiada. Może zaś stanowić tylko ten, kto posiada. Człowiek stanowi sam o sobie wolą, gdyż sam siebie posiada. Równocześnie zaś wola, każde rzeczywiste "chcę», potwierdza i urzeczywistnia to samo-posiadanie właściwe tylko osobie - fakt, iż jest ona sui iuris"28. A zatem, choć samoposiadanie i samopanowanie jest bardziej podstawowe niż samostanowienie, to jednak w porządku doświadczenia jako pierwsze dane jest nam samostanowienie. Jest ono, można by powiedzieć, wynikiem lub pochodną samoposiadania i samopanowania, i realizuje się poprzez poszczególne akty „chcenia”. Chcąc bowiem określonej wartości, człowiek czyni siebie takim lub innym, ale zawsze jakimś. Przecież kiedy czegoś „,chce”, tym samym stanowi o sobie, choć jego ,ja" nie jest przedmiotem intencjonalnym tego jego „chcę”. Jednakże w samym takim „chceniu” zawiera się zawsze jego przedmiotowość ${ }^{29}$.

Spełnianie czynów, a poprzez nie urzeczywistnianie siebie, łączy się z pewną cechą czynów, którą jest swoista koegzystencja ich przechodniości i nieprzechodniości. Dzięki tej właściwości działanie ludzkie utrwala się, niejako zatrzymuje się w osobie. Ten „przechodni”, a równocześnie „nieprzechodni” skutek czynów polega na tym, że człowiek - zgodnie z zasadą perfekcjoryzmu etycznego - stanowi o sobie poprzez swoje czyny ${ }^{30}$. I tak np. poprzez akt kradzieży człowiek staje się złodziejem, a przez wyratowanie $\mathrm{z}$ wody tonącego - bohaterem. Zatem skutek czynu jest przechodni, wszak czynność kra-

\footnotetext{
Tamże, s. 151-154.

Tamże, s. 152 .

Tamże, s. 152-153.

Tamże, s. 214-215.
} 
dzieży czy niesionej pomocy ustała, przeszła do przeszłości, a równocześnie nieprzechodni, gdyż utrwalił się on w danym człowieku. Poprzez zdolność samostanowienia człowiek „ukonstytuował”, „stworzył” siebie jako „złodzieja” bądź „bohatera”. Jest to możliwe dzięki samozależności człowieka w samostanowieniu, czyli posiadaniu przez człowieka wolnej woli. Przy czym sam czyn może być dokonany tylko w sposób wewnętrzny - i wówczas nazywa się „czynem wewnętrznym” (actus internus), albo dokonany zewnętrznie i wówczas jest on określany jako „czyn zewnętrzny” (actus externus) ${ }^{31}$.

Przeżywając swoje samoposiadanie, człowiek doświadcza swoistej autozależności, tzn. że nikt nie może go zmusić do „tego oto” aktu „chcenia”, ani nie może mu w nim radykalnie przeszkodzić. Owszem, może „ktos’” lub „cos'” przeszkadzać w dokonywaniu przezeń wyboru, może usiłować go zmuszać, uwarunkowywać, wywierać presje na jego wybory, ale wszystkie te okoliczności nigdy nie są w stanie radykalnie zdeterminować jego wyboru, owego osobowego aktu ,ja-chcę”. Jest to zawsze wybór podjęty przez konkretnego człowieka-osobę. Możemy powiedzieć, że wybór ten zawsze musi być dokonany „osobiście”. Widać przeto, że przeżycie „ja-chcę” jest nierozerwalnie związane z przeżyciami "mogę - nie muszę" ${ }^{32}$. Można by powiedzieć, że przeżycie „ja-chcę" leży pomiędzy tymi przeżyciami.

Analizując powyższe przeżycia, odkrywamy wolność właściwą człowiekowi, albo inaczej - wolność człowieka realizowaną przez jego wolę. „Wolność właściwa człowiekowi - pisze Wojtyła - wolność osoby poprzez wolę utożsamia się z samostanowieniem jako rzeczywistością doświadczalną i najbardziej podstawową zarazem" ${ }^{33}$. Kluczem do zrozumienia tej złożonej rzeczywistości, jaką jest wola i wolność, jest właśnie fakt samostanowienia oraz to, co go $\mathrm{w}$ strukturze osoby warunkuje, a więc samoposiadanie i samopanowanie ${ }^{34}$.

Czyn jest zawsze związany z osobą, wszak tylko osobowy byt jest zdolny do jego spełnienia. Ten kto działa, jest osobą, jest „kimś”, działającym jest zawsze „ktoś”. Zdolność spełniania czynów wskazuje na duchowy czynnik konstytuujący człowieka-osobę ${ }^{35}$, gdyż w czynie ujawnia się osobowa transcendencja, polegająca na nieusuwalnym odniesieniu czynu do prawdy. Transcendencja człowieka w czynie ujawnia się w zdolności do dania odpowiedzi wzywającej

\footnotetext{
31 Tamże, s. 160.

32 Tamże, s. 161.

33 Tamże.

34 Tamże, s. 161-163.

35 Tamże, s. 223-225.
} 
go prawdy; człowiek staje się odpowiedzialny za prawdę ${ }^{36}$. Dlatego też - pisze Wojtyła - „tak jak nie możemy oderwać osoby od duchowości, tak też nie możemy oderwać duchowości od osoby" ${ }^{37}$.

Ważnym dookreśleniem jest to, iż nazwa „ktoś”, którą określamy działający byt osobowy, przysługuje nie tylko tym, którzy aktualnie przejawiają strukturę samoposiadania i samopanowania, ale przysługuje również tym, którzy posiadają ją potencjalnie, czyli każdemu człowiekowi jako takiemu od chwili poczęcia ${ }^{38}$.

Przy omawianiu szeroko pojętych „chceń” niezwykle ważne jest rozróżnienie dwóch, zgoła odmiennych przeżyć: „ja chcę" (aktów pochodzących z dynamizmu osobowego) od "chce mi się" (aktów wypływających z natury rozumianej na sposób fenomenologiczny, a więc nie jako metafizycznie rozumianej istoty). Wymienione przeżycia są do siebie niesprowadzalne, wszak tylko przeżycie „ja chcę" zawiera w sobie moment samostanowienia. W przeżyciu „chce mi się" samostanowienie nie jest aktualizowane, gdyż nie zawiera ono w sobie dynamiki woli ${ }^{39}$.

$\mathrm{Z}$ tak rozumianej natury pochodzą wszelkie uczynnienia w człowieku. Tym, co je charakteryzuje, jest właśnie brak dynamicznej zależności od własnego „ja” człowieka, a więc tego, co istotowo określa czyny ${ }^{40}$. Ta właśnie „zależność od własnego «ja» jest podstawą wolności - podczas gdy jej brak stawia cały dynamizm właściwy danej jednostce (np. zwierzęcej) poza sferą wolności”41. Brakowi wolności odpowiada konieczność, dlatego dynamizmowi na poziomie natury przypisuje się konieczność, a dynamizmowi na poziomie osoby - wolność ${ }^{42}$.

Podsumowując dotychczasowe analizy, powiemy, że: samoposiadanie jest specyficzną, związaną z wolą właściwością osoby i jest nam ono doświadczalnie dane w przeżyciu „ja-chcę”. Tylko „ten oto” człowiek może przeżyć swój akt woli, swoje „ja-chcę", bo tylko on, jako konkretne ,ja”, jak nikt inny, posiada siebie samego i tylko on może chcieć „tego" lub „tamtego”, może „chcieć” lub może „nie chcieć”. Decydować bowiem może tylko ten, kto posiada. Zatem

36 Tenże, Transcendencja osoby w czynie a autoteleologia człowieka, [w:] tegoż, „Osoba i czyn" oraz inne studia antropologiczne, dz. cyt., s. 484.

37 Tenże, Osoba i czyn, dz. cyt., s. 224.

38 Tamże, s. 223.

39 Tamże, s. 153-175.

40 Tamże, s. 161-163.

41 Tamże, s. 163.

42 Tamże, s. 162-163. 
w przeżyciu „ja-chcę" każdy człowiek doświadcza swojego osobowego samoposiadania, dzięki któremu aktualizuje się jego samostanowienie.

\section{Zagadnienie integracji}

Oczywiście wszystkie dynamizmy człowieka są zintegrowane w podmiocie ludzkim i doświadczając ich, człowiek przeżywa siebie jako ontyczną jedność. Ten sam „ktoś” tak samo przecież tkwi u początków somatycznych i psychicznych uczynnień, jak i osobowych czynów. Kulminacyjnym punktem w doświadczeniu integracji jest „ja”, które w przypadku czynów jest ich wolnym sprawcą, natomiast uczynnienia przeżywa jako tożsame $\mathrm{z}$ nim$^{43}$. „To, co dzieje się pod postacią różnorodnych «uczynnień», jest własnością mojego «ja», co więcej - wynika zeń jako z jedynego właściwego podłoża oraz przyczyny, chociaż «ja» nie przeżywam tutaj swego przyczynowania, swego sprawczego zaangażowania, tak jak w czynach. Gdyby jednak ktokolwiek usiłował wyprowadzić owe dziania się, owe uczynnienia, z innej przyczyny poza moim własnym «ja», natrafiłby na bezwzględny sprzeciw doświadczenia" ${ }^{44}$.

Do konkretnego ludzkiego „ja” przynależą tedy zarówno działania, jak i uczynnienia. Ani bowiem moment uczynnień ani, tym bardziej, działań nie jest przecież doświadczany poza pewnym, konkretnym ludzkim „ja”45.

\section{Kilka uwag krytycznych}

Na zakończenie przeanalizujmy krytykę personalistycznie rozumianej wolności człowieka przez nurt myślenia liberalnego. Przedstawicielem pierwszego kierunku będzie Karol Wojtyła, drugiego - Leszek Kołakowski. Wybór Kołakowskiego nie jest arbitralny, przypadkowy, ale jest podyktowany jego krytycznymi wypowiedziami na temat koncepcji Wojtyły. Filozof z Oxfordu sam określa swoje stanowisko jako „liberalne”. „Podkreślam od początku pisze Kołakowski - że przyjmuję liberalne, negatywne pojęcie wolności, okre-

\footnotetext{
43 Tamże, s. 128-133.

44 Tamże, s. 129.

45 Tamże, s. 128-133.
} 
ślone jako pole działań, które prawo zostawia wyborowi jednostek..."46. Po takim oświadczeniu staje się oczywiste, iż jego pojmowanie wolności znajduje się w opozycji do zrozumienia przedstawionego przez Karola Wojtyłę - papieża Jana Pawła II. Zresztą, Kołakowski sam to przyznaje, więc nam pozostaje jedynie fakt ten odnotować i przyjąć. O koncepcji Wojtyły pisze, że dla niego ona "nie jest całkiem jasna" ${ }^{\text {" }}$, oraz że w nim „budzi opór"48. W ujęciu liberalnym bowiem „wolność to tyle, co sama zdolność wyboru”49. Odnosząc się przeto do myśli papieża wyrażonej w encyklice Veritatis splendor, Kołakowski pisał: „Otóż trzpień teoretyczny jest taki: istnieje nieusuwalna więź między wolnością i prawdą, a znaczy to, że wolność tylko w podporządkowaniu prawdzie się osiąga. W tym punkcie kluczowym nasuwają się wszelako pytania i wątpliwości, gdyż «wolność» nie jest w tym tekście wyraźnie zdefiniowana, a tym samym więź, jaka między wolnością i prawdą zachodzi, nie jest całkiem jasna" ${ }^{50}$.

Ów „trzpień” nurtował Kołakowskiego także po lekturze innej encykliki Jana Pawła II zatytułowanej Fides et ratio. Po zapoznaniu się z jej treścią pisał: „Przyznaję, że jedna sprawa, obecna w encyklice, budzi mój opór. Czytamy (par. 13), że «wolność nie wyraża się w dokonywaniu wyborów przeciw Bogu. Czy można bowiem uznać, że autentycznym przejawem wolności jest odmowa przyjęcia tego, co pozwala na realizację samego siebie?». Jest to, jak rozumiem, odwołanie się do Augustyńskiej zasady, wedle której wolność nie polega na zdolności wyboru między dobrem a złem, lecz na faktycznym wyborze dobra. Trudno mi pogodzić tę doktrynę z samym elementarnym doświadczeniem wolności i z uznaniem odpowiedzialności naszej za zło, które czynimy. Nie wiem nawet, jak tę doktrynę pogodzić $\mathrm{z}$ inną, w tejże encyklice wyrażoną, iż zło moralne «jest raną zadaną przez człowieka wyrażającego w sposób nieuporządkowany swoją wolność» (par. 80). Wydaje się, że to ostatnie wyrażenie zakłada, iż czyniąc zło, korzystamy, choćby w sposób niszczycielski,

$46 \quad$ L. Kołakowski, Gdzie jest miejsce dzieci w filozofii liberalnej, [w:] tegoż, Moje słuszne poglądy na wszystko, Kraków 2011, s. 149.

${ }_{47}$ Tenże, Prawda i wolność, co pierwsze?, [w:] tegoż, Kościół w krainie wolności. O Janie Pawle II Kościele i chrześcijaństwie, wybór i red. Z. Mentzel, Kraków 2011, s. 33.

48 Tenże, Fides et ratio. Mała uwaga o wielkiej encyklice, [w:] tegoż, Kościół w krainie wolności. O Janie Pawle II Kościele i chrześcijaństwie, wybór i red. Z. Mentzel, Kraków 2011, s. 58.

49 Tenże, Prawda i wolność, co pierwsze?, dz. cyt., s. 34.

50 Tamże, s. 33. 
z własnej wolności" ${ }^{51}$. Opinię o takim samym przekazie znajdujemy również w innej wypowiedzi autora. „Wolność - wyjaśnia Kołakowski - jest zatem dana ludziom razem z ich człowieczeństwem, jest tego człowieczeństwa fundamentem, tworzy człowieka jako coś w bycie samym wyróżnionego. Nie ma przy tym powodu, by twierdzić za św. Augustynem i Kantem, że tylko wtedy jesteśmy wolni, gdy dobro wybieramy, nie zło, że więc wolność nasza określa się przez treść wyborów, nie zaś przez samą zdolność wybierania"52.

Co wynika z przytoczonych tutaj tekstów? Przesłanie ich jest jasne. Według Kołakowskiego człowiek jest wolny z tej racji, że posiada wolną wolę, dzięki której może dokonywać wyborów, czyli jest zdolny do podejmowania działań, które świadczą o jego wolności. Wolność liberalna, wolność negatywna, chce wyrazić siebie w uwolnieniu się „od”. Oczywiście można i trzeba nawet w tym miejscu zapytać o granice owej wolności: czy taka wolność jest nieograniczona czy ograniczona? Według Kołakowskiego jest ona ograniczona. Pisze on bowiem, że „wolność niczym nie ograniczona staje się pojęciowo niemożliwa"53. Jeżeli jest ograniczona, to dlaczego i na mocy czego wyznaczający owe granice miał prawo je zakreślić? Dobrych odpowiedzi na postawione tu pytania, o czym jestem przekonany, nie ma. (W personalistycznej koncepcji Karola Wojtyły czynnikiem tym jest natura rozumiana jako istota człowieka).

Koncepcja liberalna, o czym również jestem przekonany, zawiera w sobie jeszcze jedną niepokonalną trudność. Wiąże się ona z pytaniem o „zniewolenie". Rzecz jasna, nie pytamy tutaj o zniewolenie zewnętrzne. Jeżeli bowiem „być wolnym” znaczy tyle, co „dokonywać (wolnego) wyboru” - jak chce Kołakowski - to staje się jasne, że kiedy wybieram „a” wówczas jestem wolny, ale kiedy wybieram „b”, to również jestem wolny. Wybierając „plus” - jestem wolny, ale wybierając „minus”, tak samo jestem wolny. Kiedy wybieram „światłość” - świadczę o swojej wolności i kiedy wybieram „ciemność”, wówczas także aktualizuję swoją wolność. Kiedy podejmuję wysiłki zachowania istnienia swojego i swoich bliskich - jestem wolny, ale kiedy wybieram destrukcję tychże, wtedy też jestem wolny. Czy zatem w ogóle jest sens mówić o wolności człowieka tam, gdzie nie ma możliwości wystąpienia zniewolenia? Czy rozprawiałby ktoś o świetle, gdyby nie było ani krzty ciemności? Czy podejmowałby ktoś zagadnienie prawdy, gdyby nie zachodziła rzeczywistość błędu, fałszu, pomyłki? Kiedy jestem wolny w sposób „konieczny” (wszak swoją wolną wolę

\footnotetext{
51 L. Kołakowski, Fides et ratio. Mała uwaga o wielkiej encyklice, dz. cyt., s. 58-59.

52 Tenże, Mini wykłady o maxi sprawach. Seria trzecia i ostatnia, Kraków 2000, s. 80.

53 Tenże, Gdzie jest miejsce..., dz. cyt., s. 149.
} 
posiadam w sposób niezbywalny), to czy można wtedy mówić o „wolności”? Przecież tam, gdzie jest konieczność, tam wolność nie występuje. Wolność występuje tam, gdzie nie ma konieczności, ale w wolnym wyborze dokonuje się afirmacja autoposiadania. Samoposiadanie jest źródłem, nie szczytem, wolności. I tak przedstawia ową problematykę Wojtyła. Cały szkopuł w tym, że Kołakowski twierdzi, iż coś takiego jak „samoposiadanie” tak naprawdę nigdzie nie występuje. Kwestię tę analizuje w bardzo przystępnym tekście zamieszczonym w Mini wykładach o maxi sprawach. Swoje badania rozpoczyna od ujęcia sprawy w aspekcie negatywnym, usiłując wskazać, iż coś takiego jak samoposiadanie człowieka nie daje się stwierdzić w żadnym znanym przypadku. Pisze on tak: „Cóż by to [...] być miało «posiadanie samego siebie»? Po pierwsze jest to po prostu zapewnienie, że nie mogę być własnością innego człowieka. Od kiedy niewolnictwo zostało zniesione i tam, gdzie zniesione zostało, prawo nie dopuszcza, by ktokolwiek był właścicielem człowieka; człowiek jest przeto niejako wyłączony z porządku własności, zajmuje pozycję z niczym nieporównywalną we wszechświecie; wszystko poza tym może być posiadane. Podobnie jak nie wolno nam posiadać niewolników, nie jesteśmy posiadaczami swoich dzieci, a mężowie nie są posiadaczami swoich żon (czy odwrotnie) [...]" ${ }^{54}$. Co w ogóle znaczy „posiadać”? Czy realizuje się ono w odniesieniu innych rzeczy w codziennym naszym życiu? Kołakowski odpowiada: „Jeżeli jestem prawomocnie posiadaczem pewnej rzeczy, to wolno mi, jak by się wydawało, zrobić z tą rzeczą, co mi się podoba... Tu jednak prawo zwykle nakłada ograniczenia na moją wolność: nie wolno mi, na przykład, użyć posiadanego noża do zarżnięcia sąsiada, nie wolno mi zniszczyć rzeczy w sposób zagrażający innym ludziom (na przykład wysadzić w powietrze własnego domu) [...]"55. Nie można bez ograniczeń dysponować swoimi pieniędzmi, akcjami i innymi papierami wartościowymi. A w odniesieniu do samego siebie, czy mogę swobodnie dysponować sobą? - pyta filozof z Oxfordu. I odpowiada, że tradycja chrześcijańska np. zabrania popełniania samobójstwa, zresztą nie tylko samobójstwo, ale już samookaleczenie jest czymś nagannym. Ale nawet gdy odsuniemy na bok tradycję chrześcijańską - pisze Kołakowski - i spojrzymy na omawianą kwestię w perspektywie „świeckiego rozumu”, to i wówczas musimy stwierdzić, że jeżeli instytucja niewolnictwa jest nielegalna, to i mnie nie wolno sprzedać siebie samego nikomu w niewolę. A zatem nie jestem samowłaścicielem - pisze omawiany

54 Tenże, Mini wykłady o maxi sprawach, dz. cyt., s. 30.

55 Tamże, s. 32. 
filozof. Zaprzeczeniem samoposiadania są dla Kołakowskiego obiektywnie istniejąca prawda i dobro. „Jeśli jednak wierzę, że pewne czyny są po prostu złe czy dobre same w sobie, niezależnie od wszelkiego prawodawstwa i racji utylitarnych, że więc reguły zła i dobra znam jako rzecz zastaną, gotową, nie $\mathrm{z}$ mocy mojego dekretu i nie w wyniku ustanowień prawnych, jeśli wierzę, że istnieje zło i dobro wpisane niejako w konstytucję świata, to nie jestem już w pełni właścicielem samego siebie. Mogę wprawdzie te reguły gwałcić, ale nie mogę ich unieważnić; ani ja, ani ktokolwiek nie może odebrać im mocy. Nie jestem o tyle właścicielem samego siebie, o ile poddany jestem powinnościom, o ile istnieją same w sobie prawomocne obowiązki. Które mnie otaczają. Że zaś istnieją wiążące reguły dobra i zła jako składnik czy osobna jakość bytu samego, tego nie można udowodnić w takim sensie słowa, w jakim astronom może udowodnić - pośrednio, nie zaś wprost przez obserwację - obecność pewnego niewidocznego satelity którejś z planet; nie można tego udowodnić, ściśle mówiąc, wolno jednak w to wierzyć, podobno jak wolno wierzyć w istnienie przedmiotów matematycznych, które po prostu są, niezależnie od naszych konwencji i przepisów językowych, choć i tego udowodnić się nie da. Są jednak silne racje - a ja je podzielam - by w jedno i drugie wierzyć. Jeśli tak wierzymy, wierzymy również, że nikt z nas nie jest bez ograniczeń posiadaczem samego siebie" ${ }^{56}$.

To, czego Kołakowski w żaden sposób nie mógł dostrzec, Wojtyła uczynił fundamentem swojego zrozumienia człowieka jako bytu osobowego i jego istotowego przymiotu, jakim jest wolność. Człowiek, pisał przyszły papież, właśnie dlatego jest osobą, ponieważ wykazuje w sobie strukturę samoposiadania, samopanowania, samostanowienia. Wszystkie analizowane przez Kołakowskiego przykłady badające problematykę samoposiadania prowadziły do jednej konkluzji: samoposiadanie nie jest możliwe. Z sytuacji tej możemy wyciągnąć dwa wnioski. Pierwszy, że Kołakowski nie przebadał konsekwentnie przeżycia „ja-chcę", które ma kapitalne znaczenie dla analizowanej rzeczywistości. Nie wziął jej pod uwagę zapewne dlatego, i to jest wniosek drugi, że nie znał całości dorobku Wojtyły, zwłaszcza nie zapoznał się z pismami tzw. „Wczesnego” Wojtyły, a z oryginału znał jedynie jego późniejsze teksty. Kołakowski bowiem nie polemizuje z myślą Wojtyły zawartą np. w Osobie i czynie. Zatem można domniemywać, że właśnie to opuszczenie lektury było przyczyną całego nieporozumienia. Rozminięcie się koncepcji obydwóch wymienionych autorów jest o tyle zagadkowe, że Kołakowski w rzeczy samej,

\footnotetext{
56 Tenże, Mini wykłady o maxi sprawach, dz. cyt., s. 35.
} 
w swoich badaniach natrafił na doświadczenie przez człowieka swojego niezbywalnego aktu ,ja-chcę", ale nie dostrzegł w nim samoposiadania człowieka. W jednej ze swoich rozpraw przyznaje on bowiem, iż „nikt nie ma prawa zmusić mnie, bym wybrał raczej to niż tamto" ${ }^{\text {"57 }}$. Stosownych wniosków z tego stwierdzenia jednakże nie wyprowadził.

Aby rzucić nowe światło na koncepcję Wojtyły skonfrontowaną z ujęciem Kołakowskiego, przywołajmy przykład (również niedostrzeżony przez oksfordzkiego filozofa), podany przez papieża w przemówieniu na Jasnej Górze podczas pierwszej swojej pielgrzymki do Polski. Mówił on wtedy, że matka, która "musi” wybrać dobro czuwania przy swoim chorym dziecku, nie tylko nie jest zniewolona owym wybranym dobrem, ale w nim uzyskuje swoją ludzką i macierzyńską wolność. „Nie odczuwa niewoli matka - wyjaśniał Jan Paweł II - że jest uwiązana przy chorym dziecku, lecz jako afirmację swojej wolności, jako jej spełnienie" 58 .

Według myśli Wojtyły matka staje się wolna, kiedy wstaje do chorego, płaczącego dziecka, kiedy przy swoim chorym dziecku czuwa. W wyborze tym potwierdza się ona, „zrównuje się”, spełnia się w swoim człowieczeństwie i macierzyństwie; wybiera to, kim jest; jest tym, kim być powinna według swoich istotowych wymiarów. Kiedy natomiast przyjęlibyśmy liberalną koncepcję wolności rozumianą jako zdolność wyboru, to wtedy matka bez względu na to, co wybierze, zawsze będzie wolna: zarówno wtedy, kiedy wstanie do płaczącego dziecka, jak i wtedy, gdy włoży sobie w uszy „stopery” i będzie dalej spać. Jeżeli zaś staniemy na stanowisku personalizmu głoszącego, że wola jest tylko władzą uzdalniającą nas do osiągnięcia wolności, poprzez potwierdzenie siebie, poprzez autoafirmację, wtedy powiemy, że matka, wstając do płaczącego dziecka, potwierdza siebie, staje się „bardziej”, „pełniej” tym, kim być powinna, czyli staje się bardziej sobą, staje się wolna. Człowiek zatem jest zdolny do wolności, czyli do bycia sobą, w znaczeniu - do bycia tym, kim być powinien. To zaś, kim być powinien, wyznaczają mu istotowe jego wymiary: natury, powołania, tego wszystkiego, co go istotowo określa. Kiedy działa zgodnie z tym, kim jest, zgodnie z człowieczeństwem, staje się wolny, kiedy działa przeciwnie, staje się mniej sobą, dokonuje swoistej autodestrukcji, zniewala siebie, staje się zaprzeczeniem siebie. Dzięki samoposiadaniu jesteśmy wolni „do” pełnej realizacji siebie, do zrealizowania pełni swojego

$57 \quad$ Tenże, Gdzie jest miejsce..., dz. cyt., s. 152.

58 Jan Paweł II, Przemówienia. Homilie. Polska 2 VI 1979 - 10VI 1979, Kraków 1979, s. 67. 
życiowego powołania, które swoje zwieńczenie, dzięki łasce Boże, osiągnie w zbawieniu.

Po przeprowadzonych analizach lepiej zapewne zrozumiemy też wypowiedź Karola Wojtyły - poety, który pisał:

Wolność stale trzeba zdobywać, nie można jej tylko posiadać.

Przychodzi jako dar, utrzymuje się przez zmaganie.

Dar i zmaganie wpisują się w karty ukryte, a przecież jawne.

Całym sobą płacisz za wolność - więc to wolnością nazywaj.

Że możesz płacąc ciągle na nowo siebie posiadać ${ }^{59}$.

Jeżeli można by jeszcze na zakończenie dodać coś o filozofii liberalnej i myśli Kołakowskiego, to ważnym dopowiedzeniem może być to, że filozof z Oxfordu jest liberałem niekonsekwentnym. Liberał bowiem jest człowiekiem wyzwolonym, wyzwolonym radykalnie. Czy miałoby sens mówienie o „wolności partykularnej"? Czy trochę wolny, a trochę zniewolony, to już wolny? Pytania te pojawiają się w horyzoncie stwierdzeń Kołakowskiego o istnieniu prawdy obiektywnej; twierdzenia słusznego, ale niemożliwego do uzgodnienia $\mathrm{z}$ liberalizmem. Jak pogodzić bycie wolnym poprzez swobodne, wolne wybory, z ograniczonością możliwości wyborów? Jak usunąć sprzeczność zachodzącą pomiędzy tak pojętą wolnością człowieka a równoczesnym jego podleganiem obiektywnej prawdzie i wolności; jak pogodzić „podleganie” z „byciem wolnym”? Nie można zatem nie zauważyć, że wolność człowieka w koncepcji Kołakowskiego jest ogromnie problematyczna. Więcej, nie bardzo wiadomo, czy obiektywna prawda i dobro - choć zabrzmi to tautologicznie są naprawdę dobre, albowiem, jako takie, są one przyczyną totalitarnego zniewolenia. Pisze on: „Doktryna augustiańska, według której wolność nie polega na możności wyboru między dobrem a złem, ale człowiek staje się wolnym, faktycznie wybierając dobro, może dobrze służyć ideologiom totalitarnym. Istotnie, według tej filozofii, im mniej możliwości wyboru posiadamy, to znaczy im bardziej nasze życie jest uregulowane przez przymus, przez władzę, która wie, jak odróżnić dobro od zła, tym bardziej jesteśmy wolni. Jeśli się wierzy, że większość naszych uczynków ma znaczenie moralne - to wolność doskonała uzyskuje doskonałe wcielenie w reżymie, który nie pozostawia jednostkom żadnego wyboru, to znaczy w państwie totalitarnym"60.

\footnotetext{
59 K. Wojtyła, Myślac Ojczyzna, [w:] tegoż, Poezje. Dramaty, Kraków 1979, s. 87.

60 L. Kołakowski, Gdzie jest miejsce dzieci..., dz. cyt., s. 151.
} 
Znacznie spójniejsza, choć jeszcze bardziej absurdalna, jest myśl konsekwentnego, a więc odrzucającego nawet możliwość istnienia obiektywnej prawdy, liberała Jeana-François Lyotarda, który jakiekolwiek wysiłki zmierzające do rozpoznania i głoszenia prawdy obiektywnej (które jednak przyjmuje Kołakowski) uznał nie za co innego, jak tylko przejaw tendencji totalitarnych $^{61}$. Oczywiście myślenie takie jest na wskroś szatańskie. Kiedy Jezus Chrystus mówi: „Poznacie prawdę, a prawda was wyzwoli” (J 8, 32), to Szatan, ojciec kłamstwa krzyczy, iż poznana prawda nas zniewoli. Nic przeto dziwnego, że z kręgów liberalnych rodzą się takie absurdy, jak koncepcja gender, czyli nieuznawanie naturalnej i obiektywnej płci człowieka. Według konsekwentnego liberalizmu ta obiektywna prawda o płciowości człowieka, jak wszelka obiektywna prawda, nie istnieje, a gdyby istniała, to stanowiłaby zagrożenie dla wolności człowieka, byłaby jego zniewoleniem. Dla liberalizmu głoszenie prawdy obiektywnej jest niczym innym, jak zastosowaniem wobec człowieka szykan, terroryzmu i totalitaryzmu. Przeto bez obawy pomyłki trzeba myślenie liberalne uznać nie tylko za absurdalne, ale po prostu za złe i szkodliwe; szkodliwe dla jednostki ludzkiej i dla społeczeństwa.

Człowiek prawdy nie ustanawia. Ustanawianie prawdy nie leży w mocy ani człowieka jako jednostki, ani społeczeństwa, albowiem niezależnie od subiektywnych przekonań człowieka (niekiedy prawdziwych, niekiedy błędnych) jest to, co jest i nie ma, czego nie ma - jak głosi w drugiej swej części klasyczna definicja prawdy ${ }^{62}$. Człowiek natomiast, przy pomocy rozumu, może tę obiektywną prawdę, czyli istotę poznawanego obiektu, poznać.

Wspomnijmy jeszcze o jednej kwestii, która chociaż nie została wyszczególniona w tytule, to jednak $\mathrm{z}$ omawianym tematem łączy się w sposób nierozerwalny, a mianowicie o miłości. Kołakowski pisze, po pierwsze - że samo-posiadanie człowieka nie jest możliwe i - po drugie - że człowiek nie jest wolny wówczas, kiedy „przynależy”. Takie stwierdzenia wydają się być niezrozumiałe same w sobie. Miłość bowiem, która jest pragnieniem każdego człowieka i w której człowiek najpełniej siebie realizuje, w istocie swej jest przecież przynależeniem, jak wspomniana powyżej matka przynależąca w miłości do swojego dziecka. Właśnie wtedy, kiedy w miłości „przynależy”, realizuje siebie, swoje człowieczeństwo, swoje macierzyństwo. Miłość jest

${ }^{61}$ J. F. Lyotard, Kondycja ponowoczesna. Raport o stanie wiedzy, tłum. M. Kowalska i J. Migasiński, Warszawa 1997, s. 131, 169.

${ }^{62}$ Zob. na ten temat: np. R. Rożdżeński, Filozofia poznania. Zarys problematyki, Kraków 2010, s. 63-64. 
wolnym ofiarowaniem siebie drugiemu. Ofiarować zaś można tylko to, co się posiada. Kochać może tylko człowiek, bo jest bytem osobowym, a jest nim dzięki konstytuującemu go samoposiadaniu. Ponieważ siebie posiadam, mogę siebie dla drugiego i za drugiego ofiarować. Nie posiadając siebie, nie mógłbym tego uczynić. Wolne oddanie siebie, podporządkowanie siebie dla dobra drugiego jest właśnie miłością. Poprawne odczytanie ludzkiej wolności oraz miłości przynosi zatem personalistyczna myśl Wojtyły.

Przedstawiona przezeń personalistyczna myśl pokazuje, jak starannie i wnikliwie przeniknął on rzeczywistość człowieka, dokonując dogłębnych eksploracji fundamentalnych doświadczeń antropologicznych. $Z$ jego filozoficznych badań wyłania się obraz człowieka jako osoby, istoty obdarzonej rozumem i wolną wolą, dzięki którym to władzom może on osiągnąć wolność; rozum ludzki bowiem rozpoznaje prawdę, a wola ją wybiera, jako swoje dobro. Wybierając prawdziwe moralne dobro (w odróżnieniu od dobra pozornego, czyli zła), człowiek sam staje się dobry, dobry moralnie, a więc spełnia siebie, co czyni go wolnym. Życie według tego zrozumienia pozwala na spełnienie się człowieka jako jednostki, oraz społeczności ukonstytuowanej z poszczególnych ludzi, a także staje się filozoficznym, czyli dokonanym w świetle naturalnego rozumu, zrozumieniem ewangelicznego przesłania: „poznacie prawdę, a prawda was wyzwoli”. Żadne inne postawy człowieka szukające dla siebie usprawiedliwienia w jakichkolwiek możliwych przekłamaniach tego ewangelicznego przesłania nie mogą wyzwolić, bo nie są w stanie dokonać niczego pozytywnego. Są one przecież nie czym innym, jak maksymami prowadzącymi do zniewolenia. Zwodzą one człowieka, gdyż to, o czym mówią, po prostu nie istnieje, dlatego, jako takie, właśnie są nieprawdą, czyli kłamstwem. 